\title{
Respon Air Tersedia dan Bobot Isi Tanah pada Tanaman Jagung Manis dan Brokoli terhadap Kombinasi Terak Baja dan Bokashi Sekam Padi pada Andisol, Lembang
}

\author{
Henly Yulina ${ }^{1}$, Rina Devnita² dan Rachmat Harryanto ${ }^{2}$ \\ ${ }^{1}$ Fakultas Pertanian, Universitas Wiralodra, Indramayu \\ Jl. Ir. H. Juanda KM 3 Indramayu \\ ${ }^{2}$ Fakultas Pertanian, Universitas Padjadjaran \\ *Alamat korespondensi: henlyyulina2089@unwir.ac.id
}

\begin{abstract}
Response of water available and soil bulk density on sweet corn and broccoli of steel slag and husk bokashi combination on Andisol Lembang
\end{abstract}

\begin{abstract}
The objective of this research was to find out responses of water available and soil bulk density on sweet corn and broccoli of steel slag and husk bokashi combination on Andisol Lembang. This study used a randomized block design factorial with two factors. The first factor was steel slag and the second factor was husk bokashi. Each factor onsisted of 4 levels of $0 \%, 2.5 \%, 5.0 \%$ and $7.5 \%$ with two replications. The result showed there was not interaction between steel slag and husk bokashi on water available and soil bulk density on sweet corn and broccoli. Bokashi of husk has an independent effect to water available on sweet corn while bokashi of husk has an independent effect to soil bulk density on sweet corn and broccoli.
\end{abstract}

Keywords: Steel slag, Bokashi of husk, Soil physical characteristic, Sweet corn, Broccoli

\begin{abstract}
ABSTRAK
Andisol mempunyai sifat fisika tanah yang baik, namun bermasalah dengan retensi P. Pemberian amelioran untuk mengurangi retensi $\mathrm{P}$, diharapkan dapat mempertahankan bahkan meningkatkan parameter fisika tanah tersebut. Penelitian bertujuan untuk mengetahui respon air tersedia dan bobot isi tanah pada tanaman jagnung manis dan brokoli terhadap kombinasi terak baja dengan bokashi sekam padi pada Andisol Lembang. Penelitian menggunakan Rancangan Acak Kelompok Pola Faktorial dengan dua faktor. Faktor pertama terak baja dan faktor kedua bokashi sekam padi masing- masing 4 taraf yaitu $0 \%, 2,5 \%$, 5,0\%, dan 7,5\%, diulang dua kali. Hasil penelitian menunjukkan bahwa tidak terjadi interaksi antara terak baja dengan bokashi sekam padi terhadap air tersedia dan bobot isi pada tanaman jagung manis dan brokoli. Bokashi sekam padi berpengaruh mandiri terhadap air tersedia pada jagung manis, sedangkan bokashi sekam padi berpengaruh mandiri terhadap bobot isi tanah pada jagung manis dan brokoli.
\end{abstract}

Kata Kunci: Terak baja, Bokashi sekam padi, Ketersediaan air, Bobot isi, Jagung manis, Brokoli

\section{PENDAHULUAN}

Andisol adalah tanah yang berkembang dari bahan induk abu gunung api (Devnita, 2010). Andisol mempunyai potensi tinggi untuk pertanian karena memiliki beberapa sifat fisika dan kimia tanah yang baik, seperti bobot isi tanah rendah, permeabilitas tanah tinggi, kandungan bahan organik tinggi dan kandungan unsur hara yang tinggi, meskipun demikian Andisol memiliki beberapa kendala diantaranya ketersediaan unsur $P$ yang rendah.

Luas Andisol di dunia sekitar 0,84\% dari luas daratan muka bumi dan di Indonesia mencapai sekitar 5,4 juta ha atau 2,9\% dari luas daratan Indonesia (Hikmatullah, 2010; Leamy, 1984). Luas Andisol relatif kecil, akan tetapi intensif ditanami baik untuk tanaman semusim maupun tahunan 
karena memiliki produktivitas yang tinggi. Namun demikian, Andisol memiliki beberapa kendala diantaranya ketersediaan unsur $\mathrm{P}$ yang rendah.

Rendahnya ketersediaan $\mathrm{P}$ pada Andisol disebabkan oleh fraksi koloidnya yang didominasi oleh mineral ordo kisaran pendek, seperti alofan, imogolit, ferihidrit dan kompleks Al-humus (Hardjowigeno, 2003; Tan, 1998). Alofan adalah mineral liat tanah yang sangat reaktif karena mempunyai permukaan spesifik yang luas dan mempunyai banyak gugus fungsional aktif, seperti Fe dan Al yang bermuatan positif, sehingga dapat mengikat fosfat yang bermuatan negatif (Bohn et al., 1979; Sukmawati, 2011; Uehara \& Gillman, 1981). $\mathrm{Hal}$ ini yang menyebabkan retensi $\mathrm{P}$ pada Andisol sangat tinggi lebih dari 85\%.

Silikat dan bahan organik merupakan anion yang memiliki muatan negatif yang tinggi, sehingga dapat melepaskan anion-anion seperti fosfat dari kompleks jerapan (Tan, 1998). Pada penelitian ini silikat terdapat dalam terak baja dan bahan organik dalam bentuk bokashi sekam padi. Pemberian silikat dapat melepaskan ion fosfat dari tapak jerapan dan dapat menurunkan retensi fosfat. Di sisi lain bokashi adalah bahan organik yang difermentasikan dengan Effective Microorganism 4 (EM4) yang mengandung mikroorganisme fotosintetik, lactobacillus, ragi dan fungi aktinomicetes yang dapat meningkatkan keragaman dan jumlah mikroorganisme tanah, sehingga dapat memperbaiki kesehatan dan kualitas tanah yang selanjutnya dapat memperbaiki pertumbuhan, mutu, jumlah biomassa dan produksi tanaman (Suyono dkk., 2008).

Bahan organik dapat memperbaiki sifat kimia tanah dengan meningkatkan ketersediaan $\mathrm{P}$ tanah dan menurunkan retensi fosfat melalui mekanisme reaksi asam-asam organik sebagai hasil pelapukan bahan organik yang lebih reaktif terhadap logam-logam yang dapat memfiksasi $\mathrm{P}$ dalam tanah, sedangkan terhadap sifat fisika tanah dengan membentuk dan memantapkan agregat tanah (Jamil dkk., 2006; Stevenson, 1982).

Tanah dengan agregat yang mantap akan mampu mempertahankan kondisi tanah dari serangan energi luar, seperti energi kinetik curah hujan dan pengolahan tanah (Yulnafatmawita dkk., 2012). Selain itu bahan organik mampu mengikat butir tunggal menjadi agregat dari agregat mikro menjadi agregat meso dan makro yang mempunyai ruang pori antara agregat tersebut. Semakin besar agregat yang terbentuk, ruang pori yang bersebelahan dengan agregat juga semakin besar dan bobot isi tanah semakin rendah, sehingga kapasitas tanah dalam meretensi air pun tinggi (Yulnafatmawita dkk., 2010). Penambahan bahan organik juga dapat meningkatkan biomassa tanaman, seperti biomassa tanaman jagung manis pada setiap kelas lereng (Yulnafatmawita, 2006). Hal ini menunjukkan bahwa bahan organik yang ditambahkan mampu memperbaiki kondisi zona perakaran tanaman, sehingga pertumbuhan tanaman menjadi lebih baik dan produksi biomassanya lebih tinggi.

Tanaman yang digunakan pada penelitian ini adalah jagung manis dan brokoli. Jagung manis dan brokoli merupakan tanaman hortikultura yang bernilai tinggi bagi produsen dan konsumennya. Produsen memiliki potensi untuk mendapatkan pendapatan yang lebih tinggi dari usaha yang dilakukannya karena pada umumnya komoditas sayuran memiliki harga jual dan skala komersialisasi yang lebih tinggi dibandingkan komoditas pangan, sedangkan bagi konsumen, memberikan manfaat yang baik untuk kesehatan karena memiliki kandungan gizi yang cukup tinggi (Perdana dkk., 2013). Di Jawa Barat, luas area panen jagung manis adalah 138,957 ha dengan produksi 412,020 ton dan hasil rata-rata 29,65 kuintal per ha (Nurawan dkk., 2010) dan kubis sebesar 14,439 ha dengan produksi 317,527 ton dan hasil rata-rata 21,99 ton per ha (Badan Pusat Statistik, 2013). Jagung manis dan brokoli menghasilkan buah dan biji sebagai produk pertaniannya

Unsur hara P merupakan unsur hara makro yang sangat dibutuhkan tanaman untuk pertumbuhan dan produksi tanaman, salah satunya untuk merangsang pertumbuhan akar, mempercepat kematangan buah dan biji (Rasyid, 2012; Suyono dkk., 2008). Pemberian terak baja dan bokashi sekam padi diharapkan dapat mengurangi retensi $P$, meningkatkan ketersediaan $\mathrm{P}$ tanah dan memperbaiki kondisi perakaran, sehingga akan meningkatkan biomassa tanaman.

Pengaruh pemberian terak baja dan bokashi sekam padi terhadap sifat kimia tanah telah banyak diteliti dan memberikan pengaruh yang baik terhadap sifat kimia tanah tersebut, namun pengaruhnya terhadap sifat fisika tanah belum banyak diteliti. Diharapkan pemberian terak baja dan bokashi sekam padi dapat meningkatkan ketersediaan air dan bobot isi tanah pada tanaman jagung manis dan brokoli. 


\section{BAHAN DAN METODE}

Penelitian ini dilakukan di Kebun Percobaan Balai Penelitian Tanaman Sayuran (Balitsa) Lembang. Penelitian ini mengguakan Rancangan Acak Kelompok (RAK) pola faktorial dengan dua faktor. Faktor pertama adalah terak baja dan faktor kedua adalah bokashi sekam padi, masing-masing terdiri dari empat taraf, yaitu $0 \%$, $2,5 \%, 5,0 \%$ dan $7,5 \%$ yang diulang sebanyak dua kali. Total kombinasi perlakuan adalah $4 \times 4 \times 2=32$ pot percobaan $\times 2$ tanaman $=64$ pot percobaan. Terak baja diperoleh dari PT. Krakatau Steel dan bokashi sekam padi telah dibuat di Pedca Unpad. Kombinasi perlakuan dapat dilihat pada Tabel 1.

Tabel 1. Kombinasi perlakuan terak baja dan bokashi sekam padi.

\begin{tabular}{ccccc}
\hline \multirow{2}{*}{ Terak baja (T) } & \multicolumn{4}{c}{ Bokashi sekam padi (B) } \\
\cline { 2 - 5 } & $\mathrm{b}_{0}$ & $\mathrm{~b}_{1}$ & $\mathrm{~b}_{2}$ & $\mathrm{~b}_{3}$ \\
\hline $\mathrm{t}_{0}$ & $\mathrm{t}_{0} \mathrm{~b}_{0}$ & $\mathrm{t}_{0} \mathrm{~b}_{1}$ & $\mathrm{t}_{0} \mathrm{~b}_{2}$ & $\mathrm{t}_{0} \mathrm{~b}_{3}$ \\
$\mathrm{t}_{1}$ & $\mathrm{t}_{1} \mathrm{~b}_{0}$ & $\mathrm{t}_{1} \mathrm{~b}_{1}$ & $\mathrm{t}_{1} \mathrm{~b}_{2}$ & $\mathrm{t}_{1} \mathrm{~b}_{3}$ \\
$\mathrm{t}_{2}$ & $\mathrm{t}_{2} \mathrm{~b}_{0}$ & $\mathrm{t}_{2} \mathrm{~b}_{1}$ & $\mathrm{t}_{2} \mathrm{~b}_{2}$ & $\mathrm{t}_{2} \mathrm{~b}_{3}$ \\
$\mathrm{t}_{3}$ & $\mathrm{t}_{3} \mathrm{~b}_{0}$ & $\mathrm{t}_{3} \mathrm{~b}_{1}$ & $\mathrm{t}_{3} \mathrm{~b}_{2}$ & $\mathrm{t}_{3} \mathrm{~b}_{3}$ \\
\hline
\end{tabular}

Tanah yang digunakan dalam penelitian ini diambil dari beberapa titik di Balitsa dengan kedalaman 0-20 cm. Tanah kemudian dicampurkan dengan perlakuan dan dimasukkan ke dalam 64 polybag (dengan ukuran 60x $60 \mathrm{~cm}$ ). Inkubasi dilakukan selama 4 minggu. Selama inkubasi berlangsung, secara berkala (1 minggu 2 kali) akan dilakukan penimbangan berat tanah untuk mengetahui apakah terjadi penurunan berat tanah. Jika terjadi penurunan berat tanah selama inkubasi maka dilakukan pemberian air hingga mencapai berat tanah awal (kapasitas lapang).

Penanaman benih jagung manis dengan cara ditugal atau digarit. Jagung manis mencapai fase generatif akhir sekitar 80-100 hst dengan jarak tanam $75 \mathrm{~cm} \times 25 \mathrm{~cm}$ (Zuraida, 2010). Pupuk yang digunakan adalah $300 \mathrm{~kg} / \mathrm{ha}$ Urea, $150 \mathrm{~kg} / \mathrm{ha}$ SP-36 dan $50 \mathrm{~kg} / \mathrm{ha} \mathrm{KCl}$ (Zuraida, 2010). Fase pertumbuhan vegetatif akhir berkisar antara 45-52 hari, ditandai oleh adanya cabang terakhir dari bunga jantan sebelum kemunculan bunga betina (silk/rambut tongkol) (Subekti dkk., 2007).

Brokoli dapat dipanen pada umur 72 hari setelah tanam (Wasonowati, 2009). Pupuk yang digunakan adalah $200 \mathrm{~kg} / \mathrm{ha}$ Urea, $250 \mathrm{~kg} / \mathrm{ha}$ SP-36 dan $200 \mathrm{~kg} / \mathrm{ha} \mathrm{KCl}$ dengan jarak tanam $60 \mathrm{~cm}$ x 40 $\mathrm{cm}$. Pada saat bunga sudah padat dan kompak dengan cara memotong pangkal batangnya dengan menyisakan 6-7 helai daun sebagai pembungkus bunga. Produksinya berkisar antara 15-30 ton/ha kualitas pasar (Pusat Penelitian dan Pengembangan Hortikultura, 2013).

Sampel tanah diambil pada setiap perlakuan dengan menggunakan ring sampel untuk analisis air tersedia dan bobot isi. Penentuan air tersedia dengan metode Pressure Plate Apparatus sedangkan penentuan bobot isi tanah dengan metode Bongkahan. Kegiatan analisis ketersediaan air dilakukan di Laboratorium Fisika Tanah, Departemen Ilmu Tanah dan Sumberdaya Lahan, Fakultas Pertanian, Institut Pertanian Bogor. Analisis bobot isi dilakukan di Laboratorium Konservasi dan Fisika Tanah, Departemen Ilmu Tanah dan Sumberdaya Lahan, Fakultas Pertanian, Universitas Padjadjaran

\section{HASIL DAN PEMBAHASAN}

\section{Air Tersedia pada Penanaman Jagung Manis dan Brokoli setelah Panen}

Hasil analisis statistik menunjukkan bahwa tidak terjadi interaksi antara terak baja dengan bokashi sekam padi terhadap air tersedia pada jagung manis dan brokoli. Hasil statistik menunjukkan bahwa bokashi sekam padi berpengaruh mandiri terhadap air tersedia pada jagung manis (Tabel 2), namun terak baja dan bokashi sekam padi tidak berpengaruh nyata terhadap air tersedia pada brokoli (Tabel 3).

Data pada Tabel 2 menunjukkan bahwa penambahan terak baja dan bokashi sekam padi tidak berpengaruh nyata terhadap kapasitas air tersedia pada jagung manis, namun dengan penambahan terak baja dosis 7,5\% ( $\left.\mathrm{t}_{3}\right)$ atau bokashi sekam padi dosis $2,5 \%$ (b 1$)$ sudah dapat meningkatkan kapasitas air tersedia pada jagung manis dengan masing-masing nilai $15,30 \%$ (tinggi) dan $14,79 \%$ (sedang). Peningkatan kapasitas air tersedia tertinggi terdapat pada dosis $7,5 \%$ baik pada terak baja maupun bokashi sekam padi.

Faktor lain yang memengaruhi ketersediaan air bagi tanaman selain terak baja dan bokashi sekam padi adalah perakaran. Kebutuhan air pada tanaman dapat terpenuhi dengan adanya penyerapan air oleh akar. Jumlah air yang diserap oleh akar sangat bergantung pada kandungan air tanah, kemampuan partikel tanah untuk menahan air dan kemampuan akar untuk menyerap air (Nio dkk., 2010). Perakaran 
tanaman tidak dapat berkembang atau tertekan bila kapasitas air tersedia kurang dari 10\% (Sarief, 1989). Pada penelitian ini nilai kapasitas air tersedia termasuk sedang-tinggi, sehingga perakaran tanaman jagung manis dapat berkembang dengan baik.

Tabel 2. Pengaruh mandiri terak baja dan bokashi sekam padi terhadap air tersedia pada jagung manis setelah panen.

\begin{tabular}{lc}
\hline \multicolumn{1}{c}{$\begin{array}{c}\text { Terlakuan } \\
\text { Terak baja (T) dan bokashi sekam padi (B) }\end{array}$} & $\begin{array}{c}\text { Air tersedia } \\
(\%)\end{array}$ \\
\hline to $($ Tanpa terak baja/kontrol) & $15,11 \mathrm{a}$ \\
t1 $(2,5 \%$ terak baja terhadap media tanam $)$ & $12,44 \mathrm{a}$ \\
t2 $(5,0 \%$ terak baja terhadap media tanam) & $13,75 \mathrm{a}$ \\
t3 $(7,5 \%$ terak baja terhadap media tanam) & $15,30 \mathrm{a}$ \\
\hline bo (Tanpa bokashi sekam padi/kontrol) & $12,67 \mathrm{a}$ \\
b1 $(2,5 \%$ bokashi sekam padi terhadap media tanam $)$ & $14,79 \mathrm{ab}$ \\
b2 $(5,0 \%$ bokashi sekam padi terhadap media tanam $)$ & $12,60 \mathrm{a}$ \\
b3 $(7,5 \%$ bokashi sekam padi terhadap media tanam $)$ & $16,53 \mathrm{~b}$ \\
\hline
\end{tabular}

Keterangan: Angka yang diikuti oleh huruf yang sama, tidak berbeda nyata menurut Uji Jarak Berganda Duncan pada taraf 5\%.

Kemampuan akar untuk menyerap air serta unsur-unsur hara yang terlarut di dalamnya juga dipengaruhi oleh faktor genetis, kemampuan akar untuk mentranslokasikan unsur-unsur tersebut dari akar menuju ke daun serta kemampuan akar untuk menyebarkan atau memperluas sistem perakaran pada jarak yang lebih jauh untuk memperoleh suplai hara dan air (Harjadi \& Yahya, 1988). Karakter morfologi akar akan memengaruhi satu atau lebih komponen hasil produksi karena hal ini berkaitan erat dengan jumlah air yang diserap oleh akar, efisiensi air yang diserap dan besarnya kebutuhan air pada tanaman (Passioura, 1982).

Jagung manis mempunyai akar yang lebih panjang dibandingkan dengan brokoli. Akar jagung manis dapat menembus kedalaman tanah sampai kisaran 2 m (Bahtiar dkk., 2005). Hal ini menyebabkan akar jagung manis sebenarnya dapat menyerap air dan mengikat partikel-partikel tanah lebih banyak dibandingkan brokoli. Di sisi lain penanaman yang dilakukan dalam polibag menyebabkan adanya keterbatasan ruang. Semakin dalam tanah maka tanah tersebut akan semakin padat, agregat yang terbentuk mantap dan pori mikro yang terbentuk lebih banyak (Hasanah dkk., 2010). Air yang berada dalam tanah tidak dapat bergerak karena terikat kuat oleh pori mikro dan matriks tanah, sehingga air tidak tersedia untuk tanaman (Sarief, 1989).

Tabel 3. Pengaruh mandiri bokashi sekam padi terhadap air tersedia pada brokoli setelah panen.

\begin{tabular}{lc}
\hline \multicolumn{1}{c}{ Perlakuan bokashi sekam padi (B) } & Air tersedia (\%) \\
\hline b0 (Tanpa bokashi sekam padi / kontrol) & $13,73 \mathrm{a}$ \\
b1 $(2,5 \%$ bokashi sekam padi terhadap media tanam) & $13,75 \mathrm{a}$ \\
b2 $(5,0 \%$ bokashi sekam padi terhadap media tanam) & $17,85 \mathrm{~b}$ \\
b3 $(7,5 \%$ bokashi sekam padi terhadap media tanam) & $18,20 \mathrm{~b}$ \\
\hline
\end{tabular}

Keterangan: Angka yang diikuti oleh huruf yang sama, tidak berbeda nyata menurut Uji Jarak Berganda Duncan pada taraf 5\%.

Data pada Tabel 3 menunjukkan bahwa penambahan bokashi sekam padi dapat meningkatkan kapasitas air tersedia pada brokoli. Peningkatan kapasitas air tersedia tertinggi terdapat pada perlakuan $\mathrm{b}_{3}(7,5 \%)$, namun pemberian bokashi sekam padi dengan dosis $5,0 \%$ (b2) pada brokoli sudah dapat meningkatkan kapasitas air tersedia, sekaligus berbeda nyata dengan kontrol dan $b_{1}$, namun tidak berbeda nyata dengan b3. Nilai kapasitas air tersedia 17,85\% termasuk tinggi (Sarief, 1989), sehingga perakaran brokoli dapat tumbuh dan berkembang dengan baik. 
Dalam penelitian ini terak baja tidak berpengaruh nyata terhadap ketersediaan air tanah pada tanaman brokoli. Hal ini disebabkan oleh distribusi akar brokoli yang menyebar ke segala arah pada kedalaman antara 30-50 cm (Haryanto dkk., 2003) akan memengaruhi kemampuan tanaman untuk mencukupi kebutuhan air dan unsur haranya. Selain itu pemberian bokashi sekam padi secara volumetrik lebih banyak dibandingkan terak baja.

Bokashi sekam padi berkontribusi terhadap kelimpahan C-organik tanah yang apabila terdekomposisi akan dihasilkan humus yang akan mengikat partikel-partikel tanah menjadi agregat dari agregat mikro menjadi agregat makro (Watt et al., 1993). Semakin banyak agregat makro maka pori meso dan makro yang terbentuk juga lebih banyak dibandingkan pori mikro, sehingga air lebih tersedia bagi tanaman.

\section{Bobot Isi Tanah pada Penanaman Jagung Manis dan Brokoli Setelah Panen}

Hasil analisis statistik menunjukkan bahwa tidak terjadi interaksi antara terak baja dengan bokashi sekam padi terhadap bobot isi tanah pada jagung manis dan brokoli setelah panen. Hasil analisis statistik menunjukkan bahwa bokashi sekam padi berpengaruh mandiri terhadap bobot isi tanah pada jagung manis dan brokoli (Tabel 4).

Tabel 4. Pengaruh mandiri bokashi sekam padi terhadap bobot isi tanah pada jagung manis dan brokoli setelah panen.

\begin{tabular}{lcc}
\hline \multicolumn{1}{c}{ Perlakuan } & \multicolumn{2}{c}{ Bobot Isi Tanah $\left(\mathrm{g} / \mathrm{cm}^{3}\right)$} \\
\cline { 2 - 3 } Bokashi Sekam Padi (B) & Jagung manis & Brokoli \\
\hline bo (Tanpa bokashi sekam padi/kontrol) & $0,90 \mathrm{a}$ & $0,79 \mathrm{a}$ \\
b1 $(2,5 \%$ bokashi sekam padi terhadap media tanam) & $0,63 \mathrm{~b}$ & $0,69 \mathrm{~b}$ \\
b2 $(5,0 \%$ bokashi sekam padi terhadap media tanam) & $0,61 \mathrm{~b}$ & $0,59 \mathrm{c}$ \\
b3 $(7,5 \%$ bokashi sekam padi terhadap media tanam) & $0,51 \mathrm{c}$ & $0,53 \mathrm{~d}$ \\
\hline
\end{tabular}

Keterangan: Angka yang diikuti oleh huruf yang sama, tidak berbeda nyata menurut Uji Jarak Berganda Duncan pada taraf $5 \%$.

Data pada Tabel 4 menunjukkan bahwa penambahan bokashi sekam padi dapat menurunkan bobot isi tanah pada jagung manis dan brokoli. Penurunan bobot isi tanah terbesar terjadi pada dosis $7,5 \%\left(b_{3}\right)$, namun pada dosis 2,5\% ( $\left.b_{1}\right)$ sudah terjadi penurunan bobot isi tanah yang berbeda nyata dengan kontrol, perlakuan $b_{2}$ dan $b_{3}$. Bobot isi ratarata kedua tanaman pada perlakuan $b_{1}\left(0,66 \mathrm{~g} / \mathrm{cm}^{3}\right)$ sudah merupakan media yang baik untuk pertumbuhan kedua tanaman, karena pada umumnya bobot isi tanah mineral berkisar antara 1,1-1,6 g/ $\mathrm{cm}^{3}$ (Hardjowigeno, 2003).

Penurunan bobot isi tanah setelah tanam disebabkan oleh perakaran tanaman yang berperan dalam menurunkan bobot isi tanah. Bobot isi merupakan petunjuk kepadatan tanah, semakin padat suatu tanah maka semakin tinggi bobot isinya yang berarti tanah semakin sulit ditembus akar tanaman. Peningkatan kandungan bahan organik tanah dapat mempertahankan kualitas fisika tanah untuk membantu perkembangan akar tanaman (Hairiah, 2000) melalui pembentukan celah-celah yang mudah ditembus akar (Kusuma dkk., 2013). Jumlah akar yang semakin banyak akan meningkatkan kemampuan tanaman untuk menyerap unsur hara oleh tanaman (Wigati dkk., 2006).

Selain itu akar tanaman akan menyumbang bahan organik dalam tanah yang berperan sebagai perekat (pengikat) partikel tanah, sehingga agregasi tanah menjadi baik, ruang pori tanah meningkat dan bobot isi menurun. Hal ini sesuai dengan pernyataan Mariana (2006) bahwa bahan organik bersifat porus, ketika diberikan ke dalam tanah akan menciptakan ruang pori di dalam tanah, sehingga bobot isi tanah menjadi berkurang.

Pada penelitian ini terak baja tidak berpengaruh nyata terhadap bobot isi tanah pada kedua tanaman. Hal ini disebabkan oleh pemberian terak baja dalam setiap polibag secara volumetrik lebih sedikit dibandingkan bokashi sekam padi, karena bobot isi terak baja yang lebih besar dibandingkan bokashi sekam padi.

\section{SIMPULAN}

Tidak terjadi interaksi antara terak baja dengan bokashi sekam padi terhadap air tersedia dan bobot isi pada tanaman jagung manis dan brokoli. Bokashi sekam padi berpengaruh mandiri terhadap 
air tersedia pada jagung manis. Peningkatan kapasitas air tersedia tertinggi terdapat pada perlakuan $b_{3}$ (7,5\%), namun pemberian bokashi sekam padi dengan dosis 5,0\% (b2) pada brokoli sudah dapat meningkatkan kapasitas air tersedia, sekaligus berbeda nyata dengan kontrol dan $b_{1}$, namun tidak berbeda nyata dengan $b_{3}$. Sedangkan bokashi sekam padi berpengaruh mandiri terhadap bobot isi tanah pada jagung manis dan brokoli. Penurunan bobot isi tanah terbesar terjadi pada dosis $7,5 \%$ (b3), namun pada dosis 2,5\% (b1) sudah terjadi penurunan bobot isi tanah yang berbeda nyata dengan kontrol, perlakuan b2 dan b3.

\section{UCAPAN TERIMA KASIH}

Penulis mengucapkan terima kasih kepada pembimbing penelitian Dr. Rina Devnita, Ir., M. S., M. Sc dan Dr. Rachmat Harryanto, Ir., M.S. Penulis menyampaikan terima kasih juga kepada Kepala Balai Penelitian Tanaman Sayuran (Balitsa), Lembang yang telah memberikan izin penggunaan lahan untuk penelitian.

\section{DAFTAR PUSTAKA}

Badan Pusat Statistik (BPS). 2013. Luas Panen, Produksi dan Produktivitas Kubis, 20092013. Tersedia online pada http://www.bps.go.id/. (diakses tanggal 25 Juni 2014).

Bahtiar, A, F Fadhly, M Rauf, A Njamuddin, dan Margaretha. 2005. Studi Karakterisasi Sistem Produksi serta Persepsi dan Sikap Pengguna Teknologi Serealia. Laporan Akhir. Balai Penelitian Tanaman Serealia, Maros.

Bohn, HL, BL McNeal, and GA O'Connor. 1979. Soil Chemistry. John Willey and Sons, New York.

Devnita, R. 2010. Genesis dan Karakteristik Tanah Abu Gunungapi. Unpad Press, Bandung.

Hairiah, K. 2000. Pengelolaan Tanah Masam secara Biologi. International Centre for Research in Agroforestry, Bogor.

Harjadi, SS, dan Yahya. 1988. Fisiologi Stress Lingkungan. Institut Pertanian Bogor, Bogor.

Haryanto, E, T Suhartini, dan E Rahayu. 2003. Sawi dan Selada. Penebar Swadaya, Jakarta.

Hasanah, U, Ardiyansyah, dan A Rosidi. 2010. Pertumbuhan awal dan evapotranspirasi aktual tanaman tomat (Lycopersicum esculentum Mill) pada berbagai ukuran agregat Inceptisols. J. Agroland. 17(1):11-17.

Hikmatullah. 2010. Sifat-sifat tanah yang berkembang dari bahan volkan di Halmahera Barat, Maluku Utara. Jurnal Ilmu-Ilmu Pertanian Indonesia (JIPI). 12(1):40-48.

Jamil, A, D Harahap, S Maryam, dan MP Yufdy. 2006. Reklamasi Lahan Sawah Tadah Hujan dengan Pupuk Fosfat dan Bahan Organik di Sumatera Utara. Balai Penelitian Tanaman Pangan (BPTP), Sumatera Utara.

Kusuma, AH, M Izzati, dan E Saptiningsih. 2013. Pengaruh penambahan arang dan abu sekam dengan proporsi yang berbeda terhadap permeabilitas dan porositas tanah liat serta pertumbuhan kacang hijau (Vigna radiata L). Buletin Anatomi dan Fisiologi. 21(1):1-9.

Leamy, ML. 1984. Andisols of the World. In: Congreso International de Suelos Volcanicos. Comunicaciones, Universidad de La Laguna Secretariado de Publicaciones, Serie Informes. 13: 368-387.

Mariana, H. 2006. Pengaruh kompos ampas tapioka dan pemberian air terhadap ketersediaan air dan pertumbuhan tanaman sawi (Brassica juncea L.) pada Entisol Wajak, Malang. Skripsi. Fakultas Pertanian. Universitas Brawijaya. Malang. [Tidak dipublikasikan].

Nio, SA, SM Tondais, dan R Butarbutar. 2010. Evaluasi indikator toleransi cekaman kekeringan pada fase perkecambahan padi (Oryza sativa L.). Jurnal Biologi. 14(1):5055.

Nurawan, A, M Djaeni, I Nurhati, dan Y Surdjanto. 2010. Keragaan Teknologi Budidaya Jagung Manis dalam Mendukung Sisitem Usahatani Terpadu di Kabupaten Majalengka dan Sukabumi. Balai Pengkajian Teknologi Pertanian Jawa Barat, Bogor.

Passioura, JB. 1982. Drought Resistance in Crops with Emphasis on Rice. International Rice Research Institute, Los Banos.

Perdana, T, J Sauman, dan E Wulandari. 2013. Penerapan teknologi untuk meningkatkan daya saing petani sayuran dalam memenuhi permintaan pasar ekspor. Warta KIML. 11(2):133-146.

Pusat Penelitian dan Pengembangan (Puslitbang) Hortikultura. 2013. Budidaya Tanaman 
Kubis. Tersedia online pada http://hortikultura.litbang.deptan.go.id/. (diakses tanggal 14 Juli 2014).

Rasyid, B. 2012. Aplikasi kompos kombinasi zeolit dan fosfat alam untuk peningkatan kualitas tanah Ultisol dan produktivitas tanaman jagung. Jurnal Agrisistem. 8(1):13-22.

Sarief. ES. 1989. Fisika-Kimia Tanah Pertanian. C.V. Pustaka Buana, Bandung.

Stevenson, FT. 1982. Humus Chemistry. John Wiley and Sons, New York.

Subekti, NA, Syafruddin, R Efendi, dan S Sunarti. 2007. Morfologi Tanaman dan Fase Pertumbuhan Jagung. Balai Penelitian Tanaman Serealia, Sulawesi.

Sukmawati. 2011. Jerapan P pada Andisol yang berkembang dari tuff vulkan beberapa gunung api di Jawa Tengah dengan pemberian asam humat dan asam silikat. Media Litbang Sulteng. 4(1):30-36.

Suyono, AD, T Kurniatin, S Mariam, M Damayanti, T Syammusa, A Yuniarti, E Trinurani, dan Y Machfud. 2008. Pupuk dan Pemupukan. Unpad Press, Bandung.

Tan, K. H. 1998. Principles of Soil Chemistry. Marcel Decker Inc., New York.

Uehara, G, and G Gillman. 1982. The Mineralogy, Chemistry and Physics of Tropical Soil with Variable Charge Clays. Westview Press, Boulder, Colorado.

Yulnafatmawita. 2006. Hubungan antara status Corganik tanah dan stabilitas agregat Ultisol Limau Manis akibat perubahan penggunaan lahan. J. Solum. 3(2):75-82.
Yulnafatmawita, A, Saidi, Gusnidar, Adrinal, dan Suyoko. 2010. Peranan bahan hijauan tanaman dalam peningkatan bahan organik dan stabilitas agregat tanah Ultisol Limau Manis yang ditanami jagung (Zea mays). J. Solum. 7(1):37-48.

Yulnafatmawita, A, RA Naldo, dan A Rasyidin. 2012. Analisis sifat fisika ultisol tiga tahun setelah pemberian bahan organik segar di daerah tropis basah Sambar. J. Solum. 9(2):91-97.

Wasonowati, C. 2009. Kajian Saat Pemberian Pupuk Dasar Nitrogen dan Umur Bibit pada Tanaman Brokoli (Brassica oleraceae var. Italica Planck). Agrovigor. 2(1):14-22.

Watt, M, ME Mc Cully, and CE Jeffree.1993. Plant and bacterial mucilages of the maize rhizosphere: comparison of their soil binding properties and histochemistry in a model system. Plant Soil. 151:151-165.

Wigati, ES, A Syukur, dan DK Bambang. 2006. Pengaruh takaran bahan organik dan tingkat kelengasan tanah terhadap serapan fosfor oleh kacang tunggak di tanah pasir pantai. Jurnal Ilmu Tanah dan Lingkungan. 6(2):52-58.

Zuraida, R. 2010. Usaha Tani Padi dan Jagung Manis pada Lahan Tadah Hujan untuk Mendukung Ketahanan Pangan di Kalimantan Selatan (Kasus di Kec. Landasan Ulin Kotamadya Banjarbaru). Prosiding Pekan Serealia Nasional. Balai Penelitian Tanaman Serealia. Sulawesi Selatan. Hlm. 597-601. 